\title{
PENGARUH KEPUASAN NASABAH DAN CITRA PERUSAHAAN TERHADAP LOYALITAS PELANGGAN (STUDI KASUS PADA PT BPR ARTHAGUNA MANDIRI CABANG GARUT)
}

\author{
${ }^{1}$ Jajang Sugiat \\ ${ }^{1}$ STIE Yasa Anggana, Garut \\ Email:jajangy_anggana@yahoo.co.id
}

\begin{abstract}
ABSTRAK
Dalam rangka meningkatkan loyalitas dari para nasabahnya, PT BPR Arthaguna Mandiri Cabang Garut terus berusaha untuk melakukan berbagai cara dalam memuaskan nasabahnya. Kepuasan Nasabah dan Citra Perusahaan merupakan faktor yang mampu meningkatkan Loyalitas Nasabah. Dengan Kepuasan Nasabah dan Citra Perusahaan yang baik maka loyalias nasabah akan dapat meningkat. Tujuan penelitian ini adalah untuk mengetahui Pengaruh Kepuasan Nasabah dan Citra Perusahaan terhadap Loyalitas Pelanggan pada PT BPR Arthaguna Mandiri Cabang Garut. Untuk dapat membuktikan Pengaruh Kepuasan Nasabah dan Citra Perusahaan terhadap Loyalitas Pelanggan pada PT BPR Arthaguna Mandiri Cabang Garut, penulis melakukan pengumpulan data melalui pembuatan instrumen berupa kuesioner, dalam kuesioner diberikan pernyataan yang didalamnya berisikan indikator dari variabel X1 (Kepuasan Nasabah) dan Citra Perusahaan (X2) sebagai variabel bebas (Independen) dan variable Y (Loyalitas Pelanggan) sebagai variable terikat (Dependen). Selanjutnya kuesioner disebarkan kepada 99 orang responden yang merupakan pegawai PT BPR Arthaguna Mandiri Cabang Garut. Instrument yang dibuat melalui pengujian validitas dan reliabilitas dan hasilnya valid karena tiap item menghasil nilai $r$ berkisar lebih dari 0,30 dan reliabel karena tiap intrumen menghasilkan nilai berkisar lebih dari 0,60 sehingga dapat digunakan untuk pengukuran dalam rangka pengumpulan data. Dalam menganalisis data, penulis digunakan teknik statistik korelasi rank spearman sebagai tekhnik korelasi dan uji determinasi sederhana dan Uji korelasi dan determinasi ganda, Uji Hipotesis. Berdasarkan hasil perhitungan korelasi, dapat disimpulkan bahwa Pengaruh Kepuasan Nasabah terhadap Loyalitas Pelanggan pada PT BPR Arthaguna Mandiri Cabang Garut adalah sebesar 0,720 berarti menunjukan adanya hubungan yang searah (positif) dan kuat, dengan besarnya kontribusi 51,8\%. Nilai pengujian Signifikansi (Uji T) didapat $t_{\text {hitung }} 10,211>t_{\text {tabel }} 1,66$ maka $\mathrm{H}_{0}$ ditolak dan $\mathrm{H}_{\mathrm{a}}$ di diterima artinya terdapat pengaruh positif Kepuasan Nasabah terhadap Loyalitas pelanggan pada PT BPR Arthaguna Mandiri Cabang Garut. Pengaruh Citra Perusahaan terhadap Loyalitas Pelanggan pada PT BPR Arthaguna Mandiri Cabang Garut adalah sebesar 0,706 berarti menunjukan adanya hubungan yang searah (positif) dan kuat, dengan besarnya kontribusi $49,9 \%$. Nilai pengujian Signifikansi (Uji T) didapat thitung 9,826 > tabel 1,66 maka $\mathrm{H}_{0}$ ditolak dan $\mathrm{H}_{\mathrm{a}}$ di diterima artinya terdapat pengaruh positif Citra Perusahaan terhadap Loyalitas pelanggan pada PT BPR. Pengaruh Kepuasan Nasabah dan Citra Perusahaan terhadap Loyalitas Pelanggan pada PT BPR Arthaguna Mandiri Cabang Garut adalah sebesar 0,753 berarti menunjukan adanya hubungan yang searah (positif) dan kuat, dengan besarnya kontribusi $56,7 \%$.sisanya sebesar $43,3 \%$ dipengaruhi oleh faktor-faktor lain yang tidak diteliti dalam penelitian ini. Kesimpulanya bahwa terdapat Pengaruh yang searah (positif) dan kuat Kepuasan Nasabah dan Citra Perusahaan terhadap Loyalitas Pelanggan pada PT BPR Arthaguna Mandiri Cabang Garut.
\end{abstract}




\section{A. Pendahuluan}

Pertumbuhan ekonomi suatu Negara dapat ditandai dengan pertumbuhan industri perbankan yang ada dalam Negara tersebut. Semakin berkembang industri perbankan maka semakin baik pula pertumbuhan ekonomi Negara itu sendiri. Salah satu usaha jasa yang menawarkan berbagai kebutuhan masyarakat akan jasa pelayanan keuangan, maka usaha jasa perbankan selain mengedepankan profesionalisme dalam pelayanan kepada masyarakat sebagai nasabah, juga harus mengedepankan citra perusahaan yang baik. karena dapat dikatakan bahwa industri perbankan adalah merupakan industri yang menjual kepercayaan kepada masyarakat sebagai nasabahnya. Adapun faktor-faktor tersebut yang menjadi dasar pertimbangan masyarakat untuk memilih jasa perbankan, baik secra langsung maupun tidak secara langsung dapat membentuk loyalitas pada diri masyarakat akan bank yang akan di jadikan sebagai pilihan yang dipercayainya.

Perbankan merupakan salah satu bidang jasa yang bersifat profesiona (Wheiler, seperti dikutip oleh Thakar dan Kumar 2010). Professional service didefinisikan sebagai jasa yang berkarakteristik kepercayaan (credence characteristics) sehingga konsumen sulit untuk mengevaluasi meskipun telah membeli dan mengkonsumsi jasa tersebut (Parasuraman, Thakr dan Kumar 2010). Konsumen pengguna professional service benar-benar harus sepenuhnya bersandar dan percaya pada penyedia jasa karena sifat dari professional service tersebut.

Kepuasan pelanggan menjadi sesuatu yang menentukan dalam melihat keberhasilan suatu lembaga yang bergerak dibidang produksi maupun jasa pelayanan, baik yang dikelola oleh badan swasta maupun pemerintah. Cara pengungkapannya juga beragam, ada yang merumuskan "pelanggan adalah raja", "memberikan segala sesuatu yang diharapkan pelanggan", "selalu ingin pelanggan puas", dan lain sebagainya. Semakin disadari bahwa pelayanan dan kepuasan pelanggan merupakan aspek vital dalam rangka bertahan dan memenangkan persaingan. Meskipun demikian saat ini tidak mudah untuk mewujudkan semua itu.Upaya untuk mewujudkan loyalitas pelanggan tentu bukanlah hal yang mudah. Tingkat kepuasan pelanggan yang tinggi belumtentu berlanjut menjadi pembelian ulang dan peningkatan penjualan atau jumlah nasabah, baik secara kuantitas maupun kualitas. Loyalitas pelanggan nasabah merupakan faktor yang sangat diperlukan pelanggan dalam melakukan pembelian ulang.

Jill Griffin, (Buchory dan Saladin 2008: 123) mengemukakan definisi loyalitas pelanggan/ nasabah adalah a loyal customer is due who; makes regular repeat purchases, purchases across product and service lines; referes to others and demonstrates an immunity to the pull of the competition. 
Konsumen yang loyal adalah melakukan pembelian ulang secara teratur; pembelian line produk dan jasa secara marketing, merekomendasikan kepada orang lain dan terhadap bujukan pesaing. Adapun dalam industri jasa citra perushaan dan kepuasan nasabah merupakan hal yang sangat diutamakan. Pelayanan menekankan pada aspek kepuasan pelanggan sehingga dapat menciptakan kesetiaan atau loyalitas pelanggan kepada perusahaan yang memberikan kualitas yang memuaskan menurut Fandy Tjiptono, (2002: 54).

PT BPR Artaguana Mandiri merupakan lembaga keuangan mikro yang bergerak di bidang usaha penghimpunan dana masyarakat dalam bentuk simpanan (Tabungan dan Deposito) serta menyalurkanya kembali kepada masyarakat dalam bentuk pinjaman/ kredit yang dikelola secara professional serta kompeten. Adapun produk kredit seperti kredit kartini mandiri, kredit pegawai, kredit konsumtif, kredit modal kerja, kredit multiguna. Tentunya produk yang kompleks akan meberikan pelayanan bagi nasabah yang masing-masing berbeda kepentinganya.

Dalam upaya meningkatkan daya taraik nasabah, PT BPR Artahguna Mandiri mengeluarkan produk tabungan dengan bunga $3.5 \%$ /tahun, produk tabungan ini mempunyai benefit yaitu sebagai tabungan sukarela yang dapat di simpan kapanpun dan dapat diambil kapanpun, khusus produk tabungan ini bagi nasabah baru akan mendapatkan hadiah berupa Mug secara langsung sehingga dapat menarik minat nasabah, selain itu tabungan ini bisa dimiliki oleh setiap kalangan masyarakat.

Namun pada kenyataannya, dengan berbagai benefit yang ditawarkan, penjualan produk tabungan belum cukup menarik minat beli konsumen. Kualitas produk pada PT BPR Artaguna Mandiri banyak disaingi oleh kualitas produk bank lain, walaupun PT BPR Artaguna Mandiri memberikan bunga yang relatif tinggi dibandingkan bank lain. Namun dari segi hadiah tabungan masih kalah dibandingkan produk bank lain, seperti pada bank lain hadiah yang diberikan berupa emas, uang kes, motor, dan mobil. PT BPR Artaguna Mandiri tidak memiliki produk demikian, hanya fasilitas hadiah berupa Mug berlebelkan PT BPR Artaguna Mandiri. Hal tersebut dapat dilihat pada tabel 1 berikut ini : 
Tabel 1

Data Nasabah Produk Tabungan PT BPR Artaguna Mandiri Cabang Garut

Periode 2014-2015

\begin{tabular}{|c|c|c|c|}
\hline \multicolumn{2}{|r|}{ Tahun } & Jumlah Nasabah & $\begin{array}{l}\text { Kenaikan atau } \\
\text { Penurunan (\%) }\end{array}$ \\
\hline \multirow[t]{2}{*}{2014} & semester 1 & 3.595 & \\
\hline & semester 2 & 2.622 & $2 \%$ \\
\hline \multirow[t]{3}{*}{2015} & semester 1 & 1.840 & $-2 \%$ \\
\hline & semester 2 & 1.487 & $-1 \%$ \\
\hline & Jumlah & 9.544 & \\
\hline
\end{tabular}

Sumber: PT BPR Artaguna Mandiri Cabang Garut

Berdasarkan table 1.1 di atas dapat kita lihat bahwa jumlah nasabah dari setiap tahun menurun, tingkat yang paling tinggi pada tahun 2014 semester 1 dengan jumlah kenaikan 2\% dengan jumlah nasabah dan penurunan tertinggi terjadi pada tahun 2015 nasabah mengalami penurunan sebesar $-1 \%$. ini terjadi karna nasabah-nasabah banyak yang telah mendapat hadiah. Dengan kata lain, pada tahun 2015 terdapat nasabah yang sudah tidak aktif menabung. Sehingga dapat diketahui penurunan yang signifikan dibandingkan dengan nasabah yang masih aktif.

Seperti dikatakan sebelumnya, persaingan terjadi tidak hanya pada kepuasan nasabah melainkan pada citra perusahan. Kepuasan nasabah sama seperti citra perusahaan, yang menilai kepuasan pelayanan itu baik atau tidak adalah berdasarkan persepsi atau sudut pandang nasabah. Kepuasan nasabah dapat diketahui dengan cara membandingkan persepsi para pelanggan atas pelayanan yang nyata-nyata mereka terima atau peroleh (perceived sevice) dengan layanan sesungguhnya (expected service). Kepuasan nasabah hendaknya mampu memenuhi harapan nasabah dimana sudut pandang nasabah atas pelayanan mampu menciptakan citra positif dengan demikian diharapkan nasabah loyal terhadap perusahaan.

Pada kenyataan di dunia operasionalnya pada PT BPR Artaguna Mandiri Cabang Garut, masih banyak nasabah yang mengeluhkan kepuasan nasabah dan citra perusahaan pada produk tabungan PT BPR Artaguna Mandiri, hal ini karena sumber daya manusia yang belum memadai mengenai jumlah karyawan, seperti teller dan costomer service yang hanya satu orang pada masing-masing bagian, membuat para nasabah mengeluhkan karena lamanya antrian. Adapaun dalam memasarkan produknya dihadapkan pada beberapa hambatan, antara 
lain adanya persaingan produk, dari suku bunga tabungan, dan citra perusahaan, sehingga mempengaruhi minat nasabah.

Kepuasan nasabah merupakan keterkaitan positif dengan loyalitas pelanggan; berpotensi menjadi sumber pendapatan masa depan (terutama melalui pembelian ulang, cross-selling, dan upselling), menekankan biaya transaksi pelanggan di masa depan (terutama biayabiaya komunikasi, penjualan, dan layanan pelanggan). Menurut Cadotte, Woodruff \& Jenskins, (Fandy dan Chandra, 2011: 295) kepuasan dikonseptualisasikan sebagai perasaan yang timbul setelah mengevaluasi pengalaman pemakaian produk. Sedangkan menurut Buchari, (2009: 375). Image is the impression, feeling, the concepsion which the public has of a company, a conditionally created impression of an object, person or organization. Artinya Citra adalah merupakan kesan, impresi, perasaan atau konsepsi yang ada pada publik mengenai perusahaan, mengenai suatu objek, orang atau lembaga.

Adapun Undang-undang nomor 8 Tahun 1999 tentang perlindungan konsumen diperlukan seperangkat aturan hokum untuk melindungi konsumen. Aturan tersebut berupa pembentukan undang-undang perlindungan konsumen mempunyai maksud untuk memberikan perlindungan kepada konsumen menurut pasal 1 angka 1 undang-undang nomor 8 Tahun 1999 Tentang perlindungan konsumen, undang- undang perlindungan konsumen mempenuyai pengertian berupa segala upaya yang menjamin adanya kepastian hukum untuk memberi perlindungan konsumen dalam kedudukan yang seimbang dengan pelaku usaha.

Konsumen dalam pasal 1 ayat (2) UUPK disini yang di maksudkan adalah "pengguna akhir (end user) “ dari suatu produk yaitu setiap orang pemakaian barang dan /atau jasa yang tersedia dalam masyarakat, baik bagi kepentingan diri sendiri, keluarga, orang lain maupun makhluk hidup lain dan tidak untuk diperdagangkan.

Dalam undang-undang dasar 1945 pasal 28D ayat (1) yaitu berbunyi:

"setiap orang berhak atas pengakuan, jaminan, perlindungan dan kepastian hukum yang adil serta perlakuan yang sasma di hadapan hukum". Pasal tersebut pada dasarnya memberikan landasan konstitusional bagio perlindungan hukum konsumen di Indonesia, karena dalam ketentuan itu secra jelas dinyatakan bahwa menjadi hak setiap orang untuk memperoleh keamanan dan perlindungan.

Dengan demikian kepuasan nasabah dan citra perusahaan tersebuat sangatlah berpengaruh terhadap loyalitas nasabah. Sehingga Adapun Faktor-faktor pembentukan Kesetiaan/ loyalitas nasabah, menurut Kotler dan Armstrong, (Buchory dan Saladin 2008: 126), menjelaskan bahwa orang yang tingkat 
kepuasanya tinggi akan menimbulkan kesetiaan / loyalitas. Sedangkan menurut Suhartanto, (Buchory dan Saladin, 2008: 123), terdapat empat faktor yang berpengaruh terhadap kesetiaan pelanggan, yaitu swiching barrier, customer satisfaction, interpersonal bound (hubungan pribadi) dan citra.

Berdasarkan latar belakang penelitian yang terjadi, maka penulis tertarik untuk melakukan penelitian mengenai

"Pengaruh Kepuasan Nasabah dan Citra Perusahaan terhadap Loyalitas Pelanggan (Studi pada PT BPR Arthaguna Mandiri Cabang Garut").

\section{Identifikasi Masalah}

Dari uraian latar belakang dapat di simpulkan identifikasi masalah penelitian ini, antara lain :

1. Bagaimana kepuasan nasabah pada PT BPR Arthaguna Mandiri Cabang Garut.

2. Bagaimana citra perusahaan pada PT BPR Arthaguna Mandiri Cabang Garut.

3. Bagaimana loyalitas pelanggan pada PT BPR Arthaguna Mandiri Cabang Garut.

4. Bagaimana kepuasan nasabah terhadap loyalitas pelanggan pada PT BPR Arthaguna Mandiri Cabang Garut.

5. Bagaimana citra perusahaan terhadap loyalitas pelanggan pada PT BPR Arthaguna Mandiri Cabang Garut.

6. Seberapa besar pengaruh kepuasan nasabah dan citra perusahaan terhadap loyalitas pelanggan secara simultan dan parsial pada PT BPR Arthaguna Mandiri Cabang Garut.

\section{Kerangka Pemikiran}

Untuk mengetahui sejauh mana kepuasan nasabah dan citra perusahaan berpengaruh terhadap loyalitas pelanggan. Sehingga perusahaan perlu melakukan perubahan-perubahan agar perusahaan dapat melayani nasabah dengan baik dan melakukan pelayanan sesuai dengan ketentuan pelayanan perusahaan dengan baik. Pada gilirannya, perusahaan dapat meningkatkan kepuasan nasabah, di mana perusahaan memaksimumkan pengalaman pelanggan yang menyenangkan dan meminimumkan atau meniadakan pengalaman pelanggan yang kurang menyenangkan. Selanjutnya, kepuasan pelanggan berkontribusi pada terciptanya rintangan beralih (switching barriers), biaya beralih (switching costs), dan loyalitas pelanggan.

Adapun beberapa metode yang bisa dipergunakan setiap perusahaan untuk mengukur dan memantau kepuasan pelanggannya dan pelanggan pesaing, Kotler, (Tjiptono dan Chandra, 2011: 314) mengidentifikasikan empat metode untuk mengukur kepuasan pelanggan:

1. Sistem keluhan dan saran

Setiap organisasi yang berorientasi pada pelanggan (customer-oriented) perlu menyediakan kesempatan dan akses yang mudah dan nyaman bagi para pelangganya 
guna menyampaikan saran, kritik, pendapat, dan keluhan mereka. Media yang digunakan bias beruapa kotak saran yang ditempatkan di lokasi-lokasi strategis (yang mudah dijangkau atau sering dilewati pelanggan), kartu komentar (yang bias diisi langsung maupun yang dikirim via pos kepada perusahaan), saluran telepon khusus bebas pulsa, websites, dan lain-lain. Tidak semua pelanggan yang tidak puas akan menyampaikan keluhanya. Bias saja mereka langsung beralih pemasok dan tidak akan membeli produk atau menggunkaan jasa perusahaan tersebut lagi.

\section{Ghost Shopping (Mystery Shopping)}

Salah satu cara memperoleh gambaran mengenai kepuasan pelanggan adalah dengan memperkerjakan bebebrapa orang ghost shoppers untuk berperan atau berpura-pura sebagai pelanggan potensial produk perusahaan dan pesaing. Mereka diminta berinteraksi dengan staf penyedia jasa dan menggunakan produk/ jasa perusahaan.

\section{Lost Customer Analysis}

Sedapat mungkin perusahaan seyogyanya menghubungi para pelanggan yang telah berhenti membeli atau yang telah pindah pemasok agar dapat memahami mengapa hal itu terjadi dan supaya dapat mengambil kebijakan perbaikan/ penyempurnaan selanjutnya. Bukan hanya exit interview saja yang diperlukan, tetapi pemantauan customer loss ratejuga penting, di mana peningkatan customer loss rate menunjukkan kegagalan perusahaan dalam memuaskan pelanggannya. Hanya saja kesulitan penerapan metode ini adalah pada mengidentifikasi dan mengkontak matan pelanggan/ nasabah yang bersedia memberikan masukan dan evaluasi terhadap kinerja perushaan.

\section{Survei Kepuasan Pelanggan}

Sebagain besar riset kepuasan pelanggan dilakukan dengan menggunakan metode survei $(\mathrm{McNel} \&$ Lab, dikutip Peterson dan Wilson, 1992), baik survei melalui pos, telepon, e-mail, websites, maupun wawancara langsung. Melalui survei, perusahaan akan memperoleh tanggapan dan balikan secara langsung dari pelanggan dan juga memberikan kesan positif bahwa perusahaan menaruh perhatian terhadap para pelanggannya.

Oleh sebab itu, baik tidaknya kepuasan nasabah tergantung pada kemampuan penyedia jasa dalam memenuhi harapan pelanggan secara konsisten. Kata kepuasan (satisfaction) berasal dari bahasa latin "satis" (artinya cukup baik, memadai) dan "facio" (melakukan atau membuat). Kepuasan bisa diartikan sebagai "upaya pemenuhan sesuatu" atau "membuat sesuatu memadai". Menurut Philip Kotler, (Buchory dan Saladin, 2008: 119) "kepuasan merupakan tingkat perasaan dimana seseorang 
menyatakan hasil perbandingan antra hasil kerja produk/ jasa yang diterima dengan apa yang diharapkan".

Para konsumen perbankan memilih suatu bank bukan karena kebutuhan produknya saja, akan tetapi ada sesuatu yang lain yang diharapkan. Sesuatu yang lain itu sesuai dengan citra perusahaan yang terbentuk dalam dirinya. Oleh sebab itu penting sekali organisasi memberi informasi kepada publik agar dapat membentuk citra perusahaan yang baik. Istilah image atau citra mulai popular sejak tahun 1950-an, yang dikemukakan dalam berbagai konteks seperti image terhadap organisasi, image terhadap perusahaan, image nasional, image terhadap merk atau brand image, image public, sef-image dan sebagainya. Ada beberapa definisi mengenai citra/ image, "An image is the sum of beliefs, ideas, and impressions that a person has of an object" ( kotler, 1982: 57 ). Image / citra ialah kepercayaan, ide, dan impresi seseorang terhadap sesuatu. Image is the impression, feeling, the concepsion which the public has of a company, a conditionally created impression of an object, person or organization. Artinya Citra adalah merupakan kesan, impresi, perasaan atau konsepsi yang ada pada publik mengenai perusahaan, mengenai suatu objek, orang atau lembaga. Menurut Buchari alam, (2009: 375).
Citra ini tidak dapat dicetak seperti membuat barang di pabrik, akan tetapi citra ini adalah kesan yang diperoleh sesuai dengan pengetahuan dan pemahaman seseorang tentang sesuatu. Citra terbentuk dari bagaimana perusahaan melaksanakan kegiatan operasionalnya, yang mempunyai landasan utama pada segi pelayanan nasabah.

Menurut Shirley Harrison (1995: 71) dalam iman (2007) informasi yang lengkap mengenai citra perbankan meliputi empat elemen sebagai berikut:

1. Personality, merupakan keseluruhan karekteristik perusahaan yang dipahami publik saran seperti perusahaan yang dapat dipercaya dan perusahaan yang mempunyai tanggung jawab sosial.

2. Reputation, merupakan hal yang telah dilakukan perusahaan dan diyakini publik sasaran berdasarkan pengalaman sendiri maupun pihak lain seperti keamanan transaksi sebuah bank.

3. Value, merupakan nilai- nilai yang dimiliki suatu perusahaan, dengan kata lain budaya perusahaan seperti sikap manajemen yang peduli terhadap pelanggan, karyawan yang cepat tanggap terhadap pemimpin maupun keluhan pelanggan. 
4. Corporate identity, merupakan komponen- komponen yang mempermudah pengenalan publik sasaran terhadap perusahaan seperti logo, warna, dan slogan.

Citra ini tidak dapat dicetak seperti membuat barang di pabrik, akan tetapi citra ini adalah kesan yang diperoleh sesuai dengan pengetahuan dan pemahamaan seseorang tentang sesuatu. Citra terbentuk dari bagaimana perusahaan melaksanakan kegiatan operasional, yang mempunyai landasan utama pada segi layanan suatu perbankan. Sehinga perusahaan dapat memperoleh nasabah yang loyal jika kualitas dan citra dalam pelayanan perusahaan tersebut berjalan dengan baik.

Beberapa ahli mendefinisikan loyalitas seperti Oliver yang dikutip Kotler dan Keller, (2009: 138) menyatakan loyalitas (loyality) sebagai "komitmen yang dipegang secara mendalam untuk membeli atau mendukung kembali produk atau jasa yang disukai di masa depan meski pengaruh situasi dan usaha pemasaran berpotensi menyebabkan pelanggan beralih". Bagi Lovelock, Witrz dan Mussry (2011: 76) menyatakan loyalitas ialah "kesediaan pelanggan agar senantiasa menggunakan produk perusahaan dalam jangka panjang, apalagi jika menggunakan secara eksklusif, dan merekomendasikan produk-produk perusahaan kepada teman dan rekannya".
Konsep mengenai loyalitas merupakan konsep lama dalam kajian pemasaran dan selalu berkembang dengan berbagai variannya. O'Shaughnessy (1992) menyatakan bahwa hal penting dari loyalitas adalah kepercayaan, kesediaan untuk bertindak tanpa segera menghitung biayabiaya dan keuntungan-keuntungan. Selain itu loyalitas juga memberikan keuntungan yang sangat besar bagi perusahaan, karena mempengaruhi pola pembelian pelanggan dan rekomendasi gratis yang diberikan pelanggan kepada orang lain menurut Geok, (1999).

Menurut Dick dan Bansu Umar, (2003: 16) Loyalitas Pelanggan didefinisikan sebagai komitmen pelanggan terhadap siatu merek dan pemasok, berdasarkan sikap yang sangat positif dan tercermin dalam pembelian ulang yang konsisten.

Adapun menurut teori yang diungkapkan Griffin, (Hurriyati, 2010:130). Beberapa indikator yang digunakan untuk mengukur variabel loyalitas pelanggan adalah:

1. Melakukan pembelian ulang secara teratur (Makes regular repeat purchases).

2. Melakukan pembelian diluar lini produk/ jasa (Purchases across product and service lines).

3. Merekomendasikan produk (Refers other). 
4. Menujukan kekebalan dari daya tarikan produk sejenis dari pesaing (Demonstrates an immunity to the full of the competition).

Kesetiaan atau loyalitas pelanggan merupakan faktor penting yang memiliki peran yang berarti dalam kelangsungan hidup perusahaaan sedikitnya saja nasabah. Menurut Suhartanto, (Buchory dan Saladin 2008: 125), ada empat manfaat utama timbulnya kesetiaan pada diri konsumen, yaitu:

1. Customer retention.

Artinya kesetiaan dapat meningkatkan pembelian konsumen. Pelanggan cenderung akan mengkonsumsi jasa pada suatu perusahaan secara berulangulang dan terus menerus pada suatu kurun waktu tertentu.

\section{Word of mouth communication.}

Artinya, komunikasi dari mulut ke mulut yang menceritakan pengalaman yang baik, saecara tidak langsung membentuk perusahaan dalam menarik pelanggan.

3. Cost lowering.

Artinya, semakin banyak pelanggan yang setia maka dapat mengurangi biaya perusahaan untuk melayani konsumennya.
4. Employee retention.

Dengan mempunyai pelanggan yang setia dan puas terhadap jasa yang diterima maka akan menimbulkan interaksi yang positif antara karyawan dengan pelanggan yang mengakibatkan turnover karyawan dapat dikurangi.

Adapun Faktor-faktor pembentukan Kesetiaan/ loyalitas nasabah, menurut Kotler dan Armstrong, (Buchory dan Saladin 2008: 126) menjelaskan bahwa orang yang tingkat kepuasanya tinggi akan menimbulkan kesetiaan/ loyalitas. Sedangkan menurut Suhartanto, (Buchory dan Saladin 2008: 123), terdapat empat faktor yang berpengaruh terhadap kesetiaan pelanggan, yaitu swiching barrier, customer satisfaction, interpersonal bound (hubungan pribadi) dan citra.

Berdasarkan uraian di atas dapat disimpulkan bahwa loyalitas pelanggan dipengaruhi beberapa faktor, termasuk kepuasan nasabah dan citra perusahaan terhadap loyalitas pelanggan, dapat digambarkan dalam struktur pradigma penelitian dalam usulan penelitian ini sebagai berikut: 
"Pengaruh kepuasan nasabah dan citra perushaan terhadap loyalitas pelanggan"

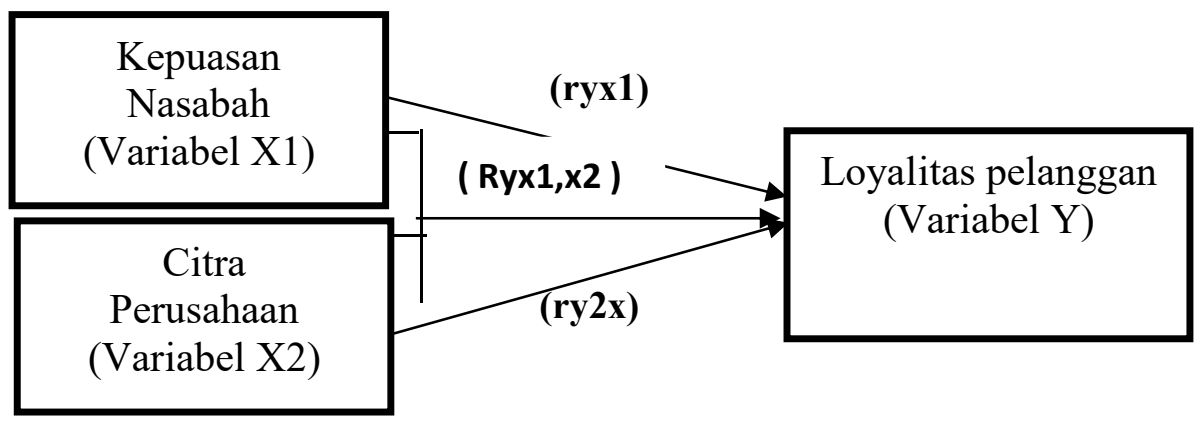

Gambar 1

Struktur Paradigma Penelitian

Pengaruh Kepuasan Nasabah dan Citra perusahaan Terhadap Loyalitas Pelanggan Pada PT Bpr Arthaguan Mandiri Cabang Garut

Keterangan:

$\mathrm{X} 1$

$\mathrm{X} 2$

Y

ryx1

ryx2

Ryx1x2

$=$ Kepuasan Nasabah

$=$ Citra Perusahaan

$=$ Loyalitas Pelanggan

$=$ Besarnya pengaruh kepuasan nasabah terhadap loyalitas pelanggan

= Besarnya pengaruh citra perusahaan terhadap loyalitas pelanggan

= Besarnya pengaruh kepuasan nasabah dan citra perusahaan secara simultan terhadap loyalitas nasabah.

\section{Hipotesis}

Menurut Sugiyono (2013: 93)

"Hipotesis merupakan jawaban sementara terhadap rumusan masalah penelitian, oleh karena itu rumusan masalah penelitian biasanya disusun dalam bentuk kalimat pernyataan". Dikatakan sementara karena jawaban baru didasarkan pada teori yang relevan, belum didasarkan pada fakta-fakta empiris yang diperoleh melalui pengumpulan data.

Dalam penelitian ini, penulis mengajukankan hipotesis sebagai berikut:
1. Kepuasan nasabah $\left(\mathrm{X}_{1}\right)$ berpengaruh terhadap loyalitas pelanggan $(\mathrm{Y})$ pada PT BPR Artaguna Mandiri Cabang Garut.

2. Citra perusahaan $\left(\mathrm{X}_{2}\right)$ berpengaruh terhadap loyalitas pelanggan $(\mathrm{Y})$ pada PT BPR Artaguna Mandiri Cabang Garut

3. Kepuasan nasabah $\left(\mathrm{X}_{1}\right)$ dan Citra perusahaan $\left(\mathrm{X}_{2}\right)$ secara bersama-sama berpengaruh terhadap loyalitas pelanggan (Y) pada PT BPR Artaguna Mandiri Cabang Garut. 


\section{B. METODE PENELITIAN}

\section{Metode Penelitian Yang Di Gunakan}

Pendekatan yang digunakan dalam penelitian ini adalah pendekatan kuantitatif dengan metode deskriptif. Pendekatan kuantitatif mengutamakan objektivitas desain penelitian dengan mengutamakan angkaangka dengan pengolahan statistik. Adapun metode deskriptif merupakan metode penelitian yang bertujuan untuk mendeskripsikan suatu keadaan atau fenomena-fenomena apa adanya. Dalam metode deskriptif, peneliti tidak melakukan manipulasi atau memberikan perlakuaanperlakuan tertentu terhadap objek penelitian (Sugiyono, 2010: 18). Dalam penelitian ini, metode deskriptif digunakan untuk menggambarkan tentang variabel-variabel yang akan diteliti.

\section{Operasionalisasi Variabel Penelitian}

Untuk mempermudah penelitian dan menyamakan pemahaman dari variabel yang akan diteliti, peneliti membuat definisi operasional sebagai berikut

1) Variabel Independen atau Variabel Bebas Pada penelitian yang dilakukan oleh penulis variabel independen $\left(\mathrm{X}_{1}\right)$ adalah Kepuasan Nasabah, $\left(\mathrm{X}_{2}\right)$ adalah Citra perusahaan.

2) Variabel dependen atau Variabel Terikat Pada penelitian yang dilakukan oleh penulis variabel dependen (Y) adalah Loyalitas Pelanggan.
Adapun deskrisi dari operasional variabenya dapat dilihat pada lampiran.

\section{Data yang diperlukan dan Sumbernya}

Data dan informasi yang digunakan dalam penelitian ini adalah meliputi dua jenis data, yaitu :

1. Data primer yaitu data yang diperoleh secara langsung dari tempatobjek penelitian, misalnya melalui wawancara. Observasi dan penyebaran angket/kuesioner (Sugiyono, 2010: 156).

2. Data Sekunder yaitu data yang telah dimuat atau diterbitkan oleh individu atau organisasi dalam suatu penerbitan atau penelitian, data ini biasanya telah tersedia dan diperoleh dengan cara membaca laporan-laporan yang telah ada. Biasanya data ini diperoleh secara tidak langsung dalam bentuk laporan, dokumen, literatur, buku-buku dan lain-lain yang ada kaitannya dengan data-data yang diperlukan dalam penelitian (Sugiyono, 2010: 156).

\section{Teknik Pengumpulan Data}

Dalam penelitian ini digunakan beberapa teknik pengumpulan data sebagai berikut;

1. Observasi

Observasi menurut Hadi dalam Sugiyono (2013: 203 ) observasi merupakan suatu proses yang kompleks, suatu proses yang tersusun dan berbagai proses biologis dan psikologis, dimana dua diantara yang 
terpenting adalah proses - proses pengamatan dan ingatan.

2. Wawancara

Menurut Sugiyono (2013: 194)

Wawancara yaitu teknik pengumpulan data apabila penelitian ingin melakukan studi pendahuluan untuk menentukan permasalahan yang harus diteliti, dan juga apabila peneliti ingin mengetahui hal-hal dari respondennya lebih sedikit atau kecil.

3. Kuesioner (Angket)

Menurut Sugiyono (2013: 199) kuesioner yaitu teknik pengumpulan data yang dilakukan dengan cara memberi seperangkat pernyataan tertulis kepada responden untuk dijawabnya. Data tersebut diperoleh melalui penyebaran angket terhadap responden yang merupakan hasil dari pelayanan costumer service pada PT Bpr Artha guna Mandiri Cabang Garut.

4. Studi Pustaka

Menurut Hasan (2002: 45) studi kepustakaan merupakan teknik pengumpulan data dengan cara mendalami, mencermati, menelaah, dan mengidentifikasi pengetahuan yang ada dalam kepustakaan untuk menunjang penelitian.

\section{Teknik Analisis Data}

Data diperoleh dengan menggunakan pengukuran sikap melalui Skala Likert yaitu skala yang digunakan untuk mengukur sikap, pendapat dan presepsi seseorang atau sekelompok orang tentang fenomena sosial (Sugiyono, 2010: 132). Untuk keperluan analisis kuantitatif, maka jawaban ini dapat diberi nilai, misalnya:

1) Sangat Setuju/selalu/sangat positif diberi nilai 5

2) Setuju/sering/positif diberi nilai

4

3) Ragu-ragu/kadang-kadang/netral diberi nilai 3

4) Tidak setuju/hampir tidak pernah/negatif diberi nilai 2

5) Sangat tidak setuju/tidak pernah diberi nilai

Analisis data untuk menjawab rumusan masalah digunakan analisis korelasi dan regresi jamak. Analisis korelasi digunakan untuk mengkaji hubbugan antara semua variabel yang ditekiti, serta analisis regresi yang digunakan untuk mengetahui pengaruh dari Kepuasan Nasabah $\left(\mathrm{X}_{1}\right)$ dan Citra Perusahaan $\left(\mathrm{X}_{2}\right)$, terhadap Loyalitas Pelanggan (Y).

\section{Lokasi Penelitian}

Penelitian yang dilaksanakan pada PT. BPR Arthaguna Mandiri Cabang Garut, Alamat Jl. Raya Cimanuk No. 14A Kp. Pedes Kec. Tarogong Kidul Kab. Garut. Telp. ( 0262 ) 236675 Fax. ( 0262 ) 236797. 


\section{Jadwal Penelitian}

Waktu pelaksanaan penelitian di mulai dari tanggal : 12 Mei 2016 sampai 09 September 2016 dengan jadwal kegiatan sebagai berikut :

\section{DISKUSI HASIL PENELITIAN}

Kepuasan Nasabah pada PT BPR Arthaguna Mandiri Cabang Garut

Kepuasan nasabah adalah hal penting yang menjadi faktor utama yang harus diperhatikan oleh pimpinan bank. Kunci utama bank dalam mencari pelanggan yang banyak adalah dengan memberikan nilai kepuasan kepada nasabah melalui penyampaian produk dan pelayanan yang berkualitas. Hal ini dilakukan karena adanya kenyataan bahwa nasabah yang tidak puas terhadap produk yang dikonsumsinya akan meninggalkan bank tersebut dan kemudian mencari bank lain yang mampu memuaskan kebutuhannya.

Menurut Kotler, (Alma dan Saladin, 2008: 119) "kepuasan merupakan tingkat perasaan dimana seseorang menyatakan hasil perbandingan antra hasil kerja produk/ jasa yang diterima dengan apa yang diharapkan".

Membangun Kepuasan Nasabah adalah salah satu kunci keberhasilan dari aktivitas bisnis yang wajib diperhatikan. Alasannya adalah karena jika nasabah merasa tidak puas dengan produk/pelayanan yang diberikan, mustahil loyalitas terhadap perusahaan bisa baik. Apalagi kegiatan bisnis perbankan yang memiliki banyak pesaingnya, oleh karena itu PT BPR Arthaguna Mandiri Cabang Garut selalu berusaha memperbaiki produk/pelayanan yang selama ini telah berjalan untuk memuaskan keinginan dari para nasabahnya.

Prinsip Kepuasan merupakan suatu prinsip yang menyatakan bahwa usaha bank dilandasi oleh nilai yang diberikan oleh bank terhadap nasabah/pelanggan. PT BPR Arthaguna Mandiri Cabang Garut berusaha memberikan pelayanan yang dapat memberikan Kepuasan Nasabah yang mampu untuk meningkatkan loyalitas Pelanggan/Nasabah.

$$
\text { Upaya mempertahankan }
$$
nasabah/konsumen jauh lebih sulit daripada mendapatkan konsumen baru. Setiap kegiatan usaha atau bisnis akan berlomba-lomba mempertahankan konsumen dengan berbagai cara agar sang konsumen tidak pindah menjadi konsumen di tempat lain. Perlakuan konsumen sebagai raja lebih banyak dirasakan oleh jenis jenis usaha yang bergerak di bidang jasa, antara bank yang satu dengan bank yang lainnya berlombalomba memberikan pelayanan kepada nasabahnya dengan sebaik-baiknya, mulai dengan membukakan pintu masuk, ucapan "selamat pagi pak... bu...", wajah petugas yang ramah penuh senyum dari satpam sampai teller,sampai dengan hal-hal penawaran bantuan-bantuan lainnya.

PT BPR Arthaguna Mandiri Cabang Garut sendiri mempunyai cara untuk mempertahankan konsumennya yaitu : 
1. Bersikap ramah dengan tulus, disapalah konsumen dengan senyum tulus, karena konsumen harus mendapatkan kesan pertama yang ramah dan sopan.Ingat kesan pertama begitu berharga.

2. Tanyakan apa kebutuhannya. Karyawan PT BPR Arthaguna Mandiri Cabang Garut harus aktif menanyakan terlebih dahulu apa kebutuhan konsumen dengan ucapan "ada yang perlu saya bantu?".

3. Memberikan kualitas produk terbaik

4. Memberikan harga yang sewajarnya. tapi tetap dibarengi dengan kualitas yang baik

5. Menepati Janji. Diusahakan setiap janji yang di berikan kepada konsumen selalu ditepati. Mernghindari jangan sampai konsumen mondar mandir ke tempat kita hanya karena janji yang tidak bisa di tepati, waktu mereka akan terbuang garagara janji yang tidak tepat. Konsumen akan kecewa, ujung-ujungnya akan kehilangan pelanggan.

6. Menciptakan suasana kekeluargaan.

Setelah membuktikan teori-teori yang dijadikan referensi dan dengan melakukan penghitungan sesuai dengan jawaban responden dalam kuesioner mengenai Kepuasan Nasabah, maka jumlah skor yang di dapat adalah 4613, sehingga responden termasuk kedalam mendekati setuju atas Kepuasan Nasabah pada PT BPR ARTHAGUNA MANDIRI CABANG GARUT, karena terletak antara titik 3564 dan 4752. Hal ini menunjukan bahwa responden setuju terhadap Kepuasan Nasabah yang menunjang Loyalitas Konsumen pada PT BPR ARTHAGUNA MANDIRI CABANG GARUT.

\section{Citra Perusahaan pada PT BPR}

\section{Arthaguna Mandiri Cabang Garut}

Organisasi memberi informasi kepada publik agar dapat membentuk citra perusahaan yang baik. Citra terbentuk berdasarkan pengetahuan dan informasi informasi yang diterima seseorang. Efek kognitif sangat mempengaruhi proses pembentukan citra perusahaan. Citra perusahaan adalah citra dari suatu organisasi secara keseluruhan, jadi bukan citra atas produk dan pelayananya. Hal-hal positif yang dapat meningkatkan citra suatu perusahaan antara lain adalah sejarah atau riwayat hidup perusahaan yang gemilang, keberhasilan ekspor, hubungan industri yang baik, reputasi sebagai pencipta lapangan kerja dalam jumlah besar, kesediaan turut memikul tanggung jawab sosial, komitmen mengadakan riset, dan sebagainya (Jefkins, 1996).

Membangun citra perusahaan adalah salah satu kunci keberhasilan dari aktivitas bisnis yang wajib diperhatikan. Alasannya adalah karena jika citra perusahaan terbangun dengan baik, maka nasabah akan merasa percaya dan yakin akan kualitas dari produk/pelyanan yang diberikan. Apalagi kegiatan bisnis perbankan yang memiliki banyak pesaingnya, oleh karena itu PT BPR Arthaguna Mandiri Cabang Garut selalu 
berusaha memperbaiki produk/pelayanan yang selama ini telah berjalan untuk meningkatkan kepercayaan dari para nasabahnya. Sehingga akan terbentuk citra perusahaan yang baik dimata nasabah.

Setelah membuktikan teori-teori yang dijadikan referensi dan dengan melakukan penghitungan sesuai dengan jawaban responden dalam kuesioner mengenai Citra Perusahaan, maka jumlah skor yang di dapat adalah 3196, sehingga responden termasuk kedalam mendekati setuju atas Citra Perusahaan pada PT BPR ARTHAGUNA MANDIRI CABANG GARUT, karena terletak antara titik 3168 dan 3960 . Hal ini menunjukan bahwa responden setuju terhadap Citra Perusahaan yang menunjang Loyalitas Konsumen pada PT BPR ARTHAGUNA MANDIRI CABANG GARUT.

\section{Loyalitas Pelanggan pada PT BPR} Arthaguna Mandiri Cabang Garut Menurut Griffin (2002: 4) menyatakan bahwa loyalitas lebih ditujukan kepada suatu perilaku, yang ditujukan dengan pembelian rutin, didasarkam pada unit pengambilan keputusan. Selain itu, menurut Gremler dan Brown (dikutif Ali Hasan, 2008: 83) bahwa : " loyalitas adalah pelanggan yang tidak hanya membeli ulang suatu barang dan jasa tetapi juga mempunyai komitmen dan sikap yang positif terhadap perusahaan jasa, misalnya dengan merekomendasikan orang lain untuk membeli”.
Berdasarkan hasil penelitian, Loyalitas Konsumen pada PT BPR Arthaguna Mandiri Cabang Garut terkait dengan peningkatan kepercayaan dari konsumen, dapat dikatakan baik. Sehingga hal ini sudah memenuhi apa yang diharapkan oleh PT BPR Arthaguna Mandiri Cabang Garut.

Pencapaian loyalitas konsumen menunjukan sudah terpenuhinya rata-rata yang diinginkan. Hal ini dapat dilihat dari berbagai indikator yang masuk kedalam kategori kriteria penilaian interval yang baik. Adapun skor dari loyalitas konsumen itu sendiri adalah 3365, sehingga responden termasuk kedalam mendekati sangat setuju atas loyalitas konsumen pada PT BPR ARTHAGUNA MANDIRI CABANG GARUT, karena terletak antara titik 3168 dan 3960. Oleh karena itu, sebenarnya berbagai hal yang dilakukan oleh PT BPR Arthaguna Mandiri Cabang Garut telah dapat meningkatkan loyalitas dari para konsumen. Ini dibuktikan karena konsumen selalu melakukan transaksi yang teratur, mereka tetap menggunakan layanan dari PT BPR Arthaguna Mandiri Cabang Garut, tidak terpengaruh oleh pihak lain, mereka juga mengajak teman atau keluarganya untuk menjadi nasabah di PT BPR Arthaguna Mandiri Cabang Garut. Dan juga mereka menggunakan beberapa fasilitas lainnya yang ada di PT BPR Arthaguna Mandiri Cabang Garut, tidak hanya satu. Sebagaimana menurut Griffin (2005: 31), bahwa 
karakteristik konsumen/pelanggan/nasabah dapat dikatakan loyalitas adalah sebagai berikut:

1. Melakukan pembelian ulang secara teratur, Loyalitas lebih mengacu pada wujud perilaku dari unit-unit pengambilan keputusan untuk melakukan pembelian secara terus menerus terhadap barang/jasa suatu perusahaan yang dipilih. Tingkat kepuasan terhadap perusahaan akan memhubungani mereka untuk membeli kembali.

2. Menunjukan kekebalan daya tarik pesaing, Tidak mudah terhubungan oleh tarikan persaingan perusahaan sejenis lainnya.

3. Mereferensi produk kepada orang lain, Menarik pelanggan baru untuk perusahaan Pelanggan yang loyal dengan sukarela merekomendasikan perusahaan kepada teman-teman dan rekannya.

4. Membeli di luar lini produk atau jasa, Keinginan untuk membeli lebih dari produk dan jasa yang telah ditawarkan oleh perusahaan. Pelanggan yang sudah percaya pada perusahaan dalam suatu urusan maka akan percaya juga untuk urusan lain.

Dari keseluruhan indikator tersebut rata-rata responden memberikan tanggapan yang setuju bahkan sangat setuju terhadap item-item mengenai Loyalitas Konsumen, sehingga dapat dinyatakan bahwa Loyalitas Konsumen tersebut cukup baik namun belum optimal.

\section{Pengaruh Kepuasan Nasabah dan Citra Perusahaan terhadap Loyalitas Konsumen pada PT BPR Arthaguna Mandiri Cabang}

\section{Garut}

Berdasarkan hasil wawancara dengan PT BPR Arthaguna Mandiri Cabang Garut, diperoleh keterangan dan penjelasan terkait dengan Kepuasan Nasabah dan Citra Perusahaan pada PT BPR Arthaguna Mandiri Cabang Garut. Dalam rangka untuk meningkatkan loyalitas konsumen, PT BPR Arthaguna Mandiri Cabang Garut senantiasa berusaha pula untuk menanamkan dan memupuk kepercayaan pada diri konsumen.

Kepuasan Nasabah dan Citra Perusahaan terhadap loyalitas konsumen memiliki pengaruh yang cukup baik. Kepuasan Nasabah dan Citra Perusahaan merupakan faktor yang berperan dalam meningkatkan loyalitas konsumen. Seperti Menurut Kotler dan Armstrong, (Buchory dan Saladin 2008: 126) menjelaskan bahwa orang yang tingkat kepuasanya tinggi akan menimbulkan kesetiaan/ loyalitas. Sedangkan menurut Suhartanto, (Buchory dan Saladin 2008: 123), terdapat empat faktor yang berpengaruh terhadap kesetiaan pelanggan, yaitu swiching barrier, customer satisfaction, interpersonal bound (hubungan pribadi) dan citra.

Dari hasil penelitian dan pembahasan diatas, dapat diketahui bahwa Kepuasan Nasabah PT BPR Arthaguna Mandiri Cabang Garut memiliki pengaruh yang kuat dan searah terhadap loyalitas pelanggan yaitu 
0,720. sebab hasil perhitungan koefisien korelasinya berada pada interval koefisien korelasi $0.60-0.799$ dan nilai koefisien determinasi sebesar $51,8 \%$ dan dapat dikatakan bahwa besarnya kontribusi pengaruh Kepuasan Nasabah (Variable X1) terhadap Loyalitas Konsumen (Variable Y) pada PT BPR ARTHAGUNA MANDIRI CABANG GARUT adalah sebesar 51,8\% dan sisanya sebesar $48,2 \%$ dipengaruhi oleh faktor-faktor lain. Nilai pengujian Signifikansi (Uji T) didapat $t_{\text {hitung }} 10,211>$ tabel 1,66 maka $\mathrm{H}_{0}$ ditolak dan $\mathrm{H}_{\mathrm{a}}$ di diterima artinya terdapat pengaruh positif Kepuasan Nasabah terhadap Loyalitas pelanggan pada PT BPR ARTHAGUNA MANDIRI CABANG GARUT.

Untuk Citra Perusahaan PT BPR Arthaguna Mandiri Cabang Garut memiliki pengaruh yang kuat dan searah terhadap loyalitas pelanggan yaitu 0,706 . sebab hasil perhitungan koefisien korelasinya berada pada interval koefisien korelasi $0.60-0.799$ dan nilai koefisien determinasi sebesar 49,9\% dan dapat dikatakan bahwa besarnya kontribusi pengaruh Citra Perusahaan (Variable X2) terhadap Loyalitas Konsumen (Variable Y) pada PT BPR ARTHAGUNA MANDIRI CABANG GARUT adalah sebesar $49,9 \%$ dan sisanya sebesar $50,1 \%$ dipengaruhi oleh faktor-faktor lain. Nilai pengujian Signifikansi (Uji T) didapat $t_{\text {hitung }}$ 9,826 $>t_{\text {tabel }}$ 1,66 maka $\mathrm{H}_{0}$ ditolak dan $\mathrm{H}_{\mathrm{a}}$ di diterima artinya terdapat pengaruh positif Citra Perusahaan terhadap Loyalitas pelanggan pada PT BPR ARTHAGUNA MANDIRI CABANG GARUT.

Dan untuk Kepuasan Nasabah dan Citra Perusahaan PT BPR Arthaguna Mandiri Cabang Garut, memiliki pengaruh yang kuat dan searah secara simultan terhadap loyalitas pelanggan yaitu 0,753 . sebab hasil perhitungan koefisien korelasinya berada pada interval koefisien korelasi $0.60-0.799$ dan nilai koefisien determinasi sebesar $56,7 \%$ dan dapat dikatakan bahwa besarnya kontribusi pengaruh Kepuasan Nasabah (X1) dan Citra Perusahaan (Variable X2) terhadap Loyalitas Konsumen (Variable Y) pada PT BPR ARTHAGUNA MANDIRI CABANG GARUT adalah sebesar $56,7 \%$ dan sisanya sebesar 43,3\% dipengaruhi oleh faktor-faktor lain yang tidak diteliti dalam penelitian ini. Nilai pengujian Signifikansi (Uji F) didapat $\mathrm{f}_{\text {hitung }} 62,965>\mathrm{f}_{\text {tabel }} 2,359$ dengan $\mathrm{dk}$ pembilang 2, dan $\mathrm{dk}$ penyebut (n-k-1 yaitu 99-2-1=96). maka $\mathrm{H}_{0}$ ditolak dan $\mathrm{H}_{\mathrm{a}}$ di diterima artinya terdapat pengaruh positif Kepuasan Nasabah dan Citra Perusahaan secara simultan terhadap Loyalitas Pelanggan pada PT BPR ARTHAGUNA MANDIRI CABANG GARUT.

Faktor lain yang dapat mempengaruhi Loyalitas Nasabah selain kepuasan nasabah dan citra perusahaan diantaranya yaitu swiching barrier dan interpersonal bound (hubungan pribadi). Hal ini sejalan dengan menurut menurut Suhartanto, (Buchory dan Saladin 2008: 123), terdapat empat faktor yang berpengaruh 
terhadap kesetiaan pelanggan, yaitu swiching barrier, customer satisfaction, interpersonal bound (hubungan pribadi) dan citra.

\section{Kesimpulan dan Saran}

\section{Kesimpulan}

Penelitian ini bertujuan untuk mengetahui pengaruh Kepuasan Nasabah dan Citra Perusahaan terhadap Loyalitas Pelanggan pada PT BPR ARTHAGUNA MANDIRI CABANG GARUT. Dari rumusan masalah penelitian yang diajukan, serta berdasarkan analisis data yang dilakukan dan pembahasan yang telah dikemukakan pada bab sebelumnya, maka dapat ditarik beberapa kesimpulan dari penelitian ini adalah sebagai berikut :

1. Kepuasan Nasabah pada PT BPR ARTHAGUNA MANDIRI CABANG GARUT sudah sangat baik respon positif dari para responden. Hal tersebut didasarkan pada tanggapan responden yang umumnya menyatakan sangat setuju dan setuju terhadap berbagai indikator mengenai Kepuasan Nasabah. Adapun skor dari Kepuasan Nasabah itu sendiri adalah 4613, sehingga responden termasuk kedalam mendekati setuju atas Kepuasan Nasabah pada PT BPR ARTHAGUNA MANDIRI CABANG GARUT, karena terletak antara titik 3564 dan 4752.

2. Citra Perusahaan pada PT BPR ARTHAGUNA MANDIRI CABANG GARUT sudah sangat baik respon positif dari para responden. Hal tersebut didasarkan pada tanggapan responden yang umumnya menyatakan sangat setuju dan setuju terhadap berbagai indikator mengenai Citra Perusahaan. Adapun skor dari Citra Perusahaan itu sendiri adalah 3196, sehingga responden termasuk kedalam mendekati setuju atas Citra Perusahaan pada PT BPR ARTHAGUNA MANDIRI CABANG GARUT, karena terletak antara titik 3168 dan 3960. Hal ini menunjukan bahwa responden setuju terhadap Citra Perusahaan yang menunjang Loyalitas Konsumen pada PT BPR ARTHAGUNA MANDIRI CABANG GARUT.

3. Nasabah pada PT BPR ARTHAGUNA MANDIRI CABANG GARUT telah sangat loyal. Hal ini dapat dilihat dari hasil kuesioner yang disebar dan responden menjawab pada umumnya menyatakan sangat setuju dan setuju. Adapun skor dari loyalitas konsumen itu sendiri adalah 3365, sehingga responden termasuk kedalam mendekati sangat setuju atas loyalitas konsumen pada PT BPR ARTHAGUNA MANDIRI CABANG GARUT, karena terletak antara titik 3168 dan 3960.

4. Dari hasil penelitian dan pembahasan, dapat diketahui bahwa Kepuasan Nasabah PT BPR Arthaguna Mandiri Cabang Garut memiliki pengaruh yang 
kuat dan searah terhadap loyalitas pelanggan yaitu 0,720 . sebab hasil perhitungan koefisien korelasinya berada pada interval koefisien korelasi 0.60 - 0.799 dan nilai koefisien determinasi sebesar $51,8 \%$ dan dapat dikatakan bahwa besarnya kontribusi pengaruh Kepuasan Nasabah (Variable X1) terhadap Loyalitas Konsumen (Variable Y) pada PT BPR ARTHAGUNA MANDIRI CABANG GARUT adalah sebesar 51,8\% dan sisanya sebesar $48,2 \%$ dipengaruhi oleh faktor-faktor lain. Nilai pengujian Signifikansi (Uji $\mathrm{T}$ ) didapat thitung $10,211>t_{\text {tabel }} 1,66$ maka $\mathrm{H}_{0}$ ditolak dan $\mathrm{H}_{\mathrm{a}}$ di diterima artinya terdapat pengaruh positif Kepuasan Nasabah terhadap Loyalitas pelanggan pada PT BPR ARTHAGUNA MANDIRI CABANG GARUT.

5. Citra Perusahaan PT BPR Arthaguna Mandiri Cabang Garut memiliki pengaruh yang kuat dan searah terhadap loyalitas pelanggan yaitu 0,706. sebab hasil perhitungan koefisien korelasinya berada pada interval koefisien korelasi $0.60-0.799$ dan nilai koefisien determinasi sebesar $49,9 \%$ dan dapat dikatakan bahwa besarnya kontribusi pengaruh Citra Perusahaan (Variable X2) terhadap Loyalitas Konsumen (Variable Y) pada PT BPR ARTHAGUNA MANDIRI CABANG GARUT adalah sebesar $49,9 \%$ dan sisanya sebesar $50,1 \%$ dipengaruhi oleh faktor-faktor lain. Nilai pengujian Signifikansi (Uji T) didapat $t_{\text {hitung }} 9,826>t_{\text {tabel }} 1,66$ maka $\mathrm{H}_{0}$ ditolak dan $\mathrm{H}_{\mathrm{a}}$ di diterima artinya terdapat pengaruh positif Citra Perusahaan terhadap Loyalitas pelanggan pada PT BPR ARTHAGUNA MANDIRI CABANG GARUT.

6. Kepuasan Nasabah dan Citra Perusahaan PT BPR Arthaguna Mandiri Cabang Garut, memiliki pengaruh yang kuat dan searah secara simultan terhadap loyalitas pelanggan yaitu 0,753. sebab hasil perhitungan koefisien korelasinya berada pada interval koefisien korelasi $0.60-0.799$ dan nilai koefisien determinasi sebesar $56,7 \%$ dan dapat dikatakan bahwa besarnya kontribusi pengaruh Kepuasan Nasabah (X1) dan Citra Perusahaan (Variable X2) terhadap Loyalitas Konsumen (Variable Y) pada PT BPR ARTHAGUNA MANDIRI CABANG GARUT adalah sebesar $56,7 \%$ dan sisanya sebesar $43,3 \%$ dipengaruhi oleh hubungan pribadi yang tidak diteliti dalam penelitian ini. Nilai pengujian Signifikansi (Uji F) didapat $\mathrm{f}_{\text {hitung }}$ $62,965>\mathrm{f}_{\text {tabel }} 2,359$ dengan $\mathrm{dk}$ pembilang 2 , dan dk penyebut (n-k-1 yaitu 99-2-1=96). maka $\mathrm{H}_{0}$ ditolak dan $\mathrm{H}_{\mathrm{a}}$ di diterima artinya terdapat 
pengaruh positif Kepuasan Nasabah dan Citra Perusahaan secara simultan terhadap Loyalitas Pelanggan pada PT BPR ARTHAGUNA MANDIRI CABANG GARUT.

\section{Saran}

Berdasarkan hasil pembahasan yang diperoleh, maka dapat disimpulkan beberapa saran atau masukan untuk pihak perusahaan sebagai berikut:

1. Kepuasan nasabah merupakan faktor utama dalam sebuah pelayana nasabah dalam suatu perusahaan, jika nasabah merasa puas maka perusahaan tersebut di nilai baik.

2. Citra perushaan merupakan gambaran dalam suatu pelayanan prodak atau jasa dalam perushaan, sehingga perusahaan harus memberikan kesan yang baik terhadap nasabah.

3. Loyalitas pelanggan merupakan suatu keutmaan dalam suatu perusahaan, karna jika nasabah sudah di puncak loyal maka perusahaan tidak perlu melakuan promosi dan mengeluarkan biaya promosi karna nasabah loyal tersebut akan secara langsung mempromosikan perusahaan tersebut.

4. Kepuasan Nasabah dan Citra Perusahaan merupakan faktor yang paling penting bagi keberlangsungan dan keberkembangan dari usaha PT BPR ARTHAGUNA MANDIRI CABANG GARUT. Maka dari itu, PT BPR ARTHAGUNA MANDIRI
CABANG GARUT harus eningkatkan kepuasan nasabah dan nilai citra perusahaan dari para konsumen/nasabah agar mereka tetap menjadi konsumen/nasabah PT BPR ARTHAGUNA MANDIRI CABANG GARUT dan tidak berpindah ke Bank lain bahkan bisa mengajak orang terdekat mereka menjadi konsumen/nasabah PT BPR ARTHAGUNA MANDIRI CABANG GARUT.

5. Dengan terciptanya loyalitas pelanggan/Nasabah, maka Perusahan tidak perlu memasarkan/ mempromosikan, karena nasabah bisa menjadi media promosi berjalan. Mereka tanpa kita suruh akan merekomendasikan perusahaan yang mereka percaya lebih baik daripada perusahaan lain. Maka dari itu, perusahaan juga harus memberi perhatian lebih bagi konsumen/ nasabah yang sudah ada agar bisa menjadi media promosi berjalan bagi perusahaan.

6. Bagi peneliti lain yang ingin meneliti mengenai loyalitas konsumen di PT BPR ARTHAGUNA MANDIRI CABANG GARUT, diharapkan dapat meneliti variable lain selain Kepuasan Nasabah dan Citra Perusahaan seperti yaitu swiching barrier dan interpersonal bound (hubungan pribadi). 


\section{Referensi}

Arikunto. (2003). Prosedur Penelitian, Suatu Pendekatan Praktek. Edisi Kesembilan. Jakarta: Rineka Cipta.

Achnad, B., dan Saladin, D. (2008). Dasar-dasar pemasaran bank. Linda karya.

Alam, Buchari. (2009:375). Citra, Manajemen pemasaran dan pemasaran jasa, Alfabeta.

Bank Indonesia. (2001). Prinsip Mengenal Nasabah (KYC), Jakarta, Dasar-dasar pemasaran bank. Linda karya.

Griffin, J, (2002), Costomer Loyalty, How to rarn it, how to keep it, jossey bass, Manajemen pemasaran dan pemasaran jasa, Alfabeta.

Griffin, J. (2005), Customer Loyality, Dasar-dasar pemasaran bank. Linda karya.

Hermawan kartajaya. (2002), mark plus on strategy, PT Gramedia Pustaka Utama, Jakarta.

Kotler, Philip. (2000), (2000:440), Marketing Management, prentice hall inc. Manajemen pemasaran dan pemasaran jasa, Alfabeta.

Kotler, Hayes, Thomas, Bloom paul w. (2002), Marketing Professional sevices, prentice hall press, Manajemen pemasaran dan pemasaran jasa, Alfabeta.

Kotler, Philip., dan K.L Keller. (2009). Manajemen Pemasaran. Penerjemah Bob Sabana Jakarta: Erlangga.

Sugiyono. (2012). Metode Penelitian Bisnis. Bandung: Alfabeta.

Sugiyono. (2012). Metode Penelitian Kuantitatif Kualitatif dan R\&D. Cetakan Tujuh belas, Bandung: Alfabeta.

Sugiyono, (2014).Metode Penelitian Administrasi. Cetakan Dua puluh dua. Bandung: Alfabeta

Shirley Harrison. (1995: 71) dalamiman (2007), Manajemen pemasaran dan pemasaranjasa, Alfabeta.

Tjiptono, Fandy. (2011). Strategi Pemasaran. Edisi Kedua. Yogyakarta: PenerbitAndi Offset.

Tjiptono, Fandy. (2011). Service, Quality \& Satisfaction Edisi Ketiga. Yogyakarta: Penerbit Andi Offset.

Umar, H. (2007). Metode Penelitian untuk Skripsi dan Tesis Bisnis. Jakarta: Raja Grafindo Persada.

Wheiler. (1987). (Thakr dan kumar 2000), Kottler (1997) dalam sihombing, (2003: 4)

Kepuasan Pelanggan. Manajemen pemasaran dan pemasaran jasa, Alfabeta. 